\title{
HENRYK DEMBIŃSKI (1908-1941) I JEGO POGLĄDY NA ISTOTĘ SAMORZĄDU
}

W ślad za reaktywacją w 1990 r. samorządu terytorialnego na poziomie gminy z inicjatywy prof. Michała Kuleszy nakładem Wydawnictwa Przemiany rozpoczęto wydawanie I Serii Klasyki Samorządowej, zawierajacej facsimilia przedwojennych opracowań istotnych z punktu widzenia teorii samorządu terytorialnego i nauk komunalnych, a w jej ramach przypomniano obszerny artykuł Henryka Dembińskiego W poszukiwaniu form organizacyjnych przedsiębiorstw komunalnych, pierwotnie ogłoszony na łamach znaczącego czasopisma „Samorząd Terytorjalny”. Ś. Srodowisku teoretyków samorządu terytorialnego autor jest jednak znany przede wszystkim z opublikowanej dysertacji doktorskiej Osobowość publiczno-prawna samorzadu w świetle metody dogmatycznej $i$ socjologicznej ${ }^{2}$. Dzięki niej na trwale zapisał się w doktrynie prawa administracyjnego, włączając się jako 25-latek w toczącą się w latach dwudziestych i trzydziestych dyskusję na ten temat. Przez specjalistów z historii administracji i myśli administracyjnej jest nawet uznawany za wybitnego administratywistę II Rzeczypospolitej Polskiej³.

Wokół tej rozprawy, a zwłaszcza jej autora, narosło wiele nieporozumień. Dość powiedzieć, że autorstwo tej pracy przypisuje się innemu Henrykowi [Marianowi Józefowi Leonowi Ignacemu] Dembińskiemu, docentowi Uniwersytetu Jagiellońskiego i profesorowi Katolickiego Uniwersytetu Lubelskiego ${ }^{4}$, który co prawda zajmował się osobowością publicznoprawna, ale w kontekście podmiotowości państw w prawie międzynarodowym ${ }^{5}$. Z kolei dr. Dembińskiemu przypisuje się fakty z życia prof. Dembińskiego ${ }^{6}$, a on sam też wkraczał na teren prawa międzynarodowego ${ }^{7}$. Już to pokazuje, że istnieje potrzeba bliższego zajęcia się tematem. Dochodzą do tego różne pod względem merytorycznym oceny jego pracy promocyjnej Osobowość publiczno-prawna samorzadu $w$ świetle metody dogmatycznej $i$ socjologicznej, napisanej pod kierunkiem prof. Jerzego Panejko. Nawet tylko z tego punktu widzenia uznanie go dzisiaj

1 Dembiński (1930): 1-28.

2 Dembiński (1934).

${ }^{3}$ Maciejewski (2012): $202 \mathrm{n}$.

4 Żukowski (2014): 79. Zob. także opis bibliograficzny w katalogu Biblioteki Narodowej.

5 Dembiński H.M. (1934): 109 n.

${ }^{6}$ Maciejewski (2012: 203) podaje, że dr H. Dembiński doktoryzował się na podstawie pracy Autonomia celna $w$ najnowszym prawie narodów, a była to w istocie pierwsza rozprawa habilitacyjna prof. H. Dembińskiego (Strzeszewski 1958: 5 n.). Zob. także Swięcicki (1971): 111.

7 Dembiński (1930b): 497-502. 
za zwolennika naturalistycznej koncepcji samorządu terytorialnego ${ }^{8}$ budzi kontrowersję.

Henryk Dembiński znany jest bardziej jako działacz społeczny i polityczny, aniżeli prawnik i monograf samorządu terytorialnego. Tak też jest przedstawiany choćby $\mathrm{w}$ Encyklopedii $\mathrm{PWN}^{9}$. Niewątpliwie był jednym z najzdolniejszych myślicieli i działaczy społecznych młodego pokolenia Polski międzywojennej. Już za życia otaczała go legenda. „Sylwetka Henryka Dembińskiego - stwierdzał jego bliski współpracownik - głęboko wryła się w pamięć każdego, kto go znał, kto z nim współpracował, a nawet choćby zetknął się z nim tylko dorywczo"10. Opisywali go w swych wspomnieniach literaci Czesław Miłosz ${ }^{11}$ i Gustaw Herling-Grudziński ${ }^{12}$, Julian Tuwim zaś dedykował mu jeden z wierszy (zatytułowany Wiec), a Paweł Jasienica poświęcił mu dużą część swojego pamiętnika ${ }^{13}$, podobnie zresztą jak i Jerzy Putrament ${ }^{14}$. Dembiński był charakteryzowany jako porywający mówca, charyzmatyczny przywódca, błyskotliwy polemista i żarliwy publicysta. Był jednak uznawany także za człowieka dialogu. Sam przeszedł swoistą rewolucję ideową i pod wpływem kształtujących się okoliczności radykalizował się. Jego droga wiodła od Stowarzyszenia Katolickiej Młodzieży Akademickiej „Odrodzenie”, przez przewodzenie studenckim ruchom antyendeckim i prezesurę „Bratniej Pomocy” oraz dalej przez wileńskie „Żagary” i kwestionowanie podstaw ustroju kapitalistycznego, następnie przez oddalenie się od środowisk katolickich i intelektualną walkę z sanacja, a przede wszystkim przez zbliżanie się do lewicy socjalistycznej, do związania się z ruchem komunistycznym. Ostatecznie jednak powrócił do wartości chrześcijańskich i pozostawał w pewnej izolacji. Mawiano, że „chciał ochrzcić bolszewizm” 15 albo że był „kapelanem Komsomołu” ${ }^{16}$. W 1936 r. zostaje aresztowany pod zarzutem współpracy z Kominternem oraz próbę obalenia ustroju państwa i nieprawomocnie skazany w grudniu $1937 \mathrm{r}$. przez Sąd Okręgowy w Wilnie na 4 lata więzienia w jednej z najsłynniejszych spraw międzywojnia: procesie wileńskiej lewicy akademickiej i redakcji „Po prostu", a potem w maju 1939 r. uniewinniony wyrokiem Sądu Apelacyjnego w Wilnie ${ }^{17}$. Po 17 września 1939 r. początkowo współpracuje z władzami radzieckimi, obejmujac funkcje Dyrektora Archiwum Państwowego w Wilnie, ale szybko przychodzi rozczarowanie ${ }^{18}$. Dotyka go paszportyzacja i zostaje delegowany do pracy nauczycielskiej na dalekie Polesie. Po 22 czerwca $1941 \mathrm{r}$. nie został ewakuowany z Armią Czerwona i w obawie o swoje życie ukrywał się. Po denuncjacji zostaje 10 sierpnia 1941 r. zatrzymany za czynny udział

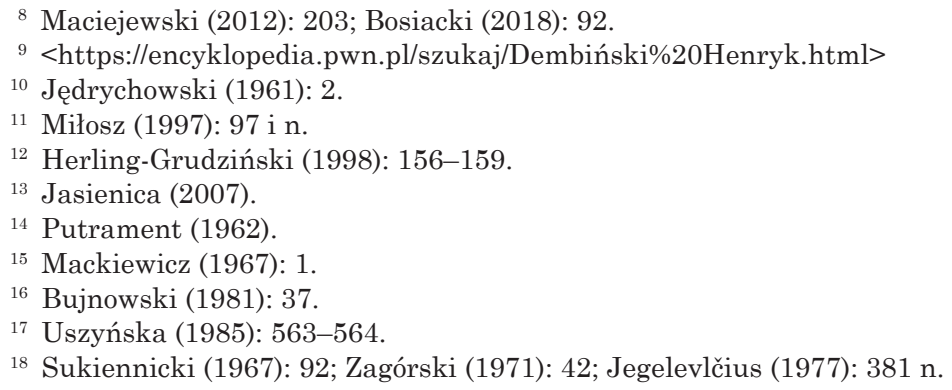

${ }^{8}$ Maciejewski (2012): 203; Bosiacki (2018): 92.

9 <https://encyklopedia.pwn.pl/szukaj/Dembiński\%20Henryk.html>

10 Jędrychowski (1961): 2.

11 Miłosz (1997): 97 i n.

12 Herling-Grudziński (1998): 156-159.

13 Jasienica (2007).

14 Putrament (1962).

15 Mackiewicz (1967): 1.

16 Bujnowski (1981): 37.

17 Uszyńska (1985): 563-564.

18 Sukiennicki (1967): 92; Zagórski (1971): 42; Jegelevlčius (1977): 381 n. 
w obchodzie święta 1 maja w Hancewiczach i dwa dni później, podczas próby ucieczki, zastrzelony przez Gestapo.

Dembiński miał polot pisarski i ostre pióro. Wśród jego ponad 150 tekstów publicystycznych ogłoszonych w ciagu 10 lat (z przerwą na roczną służbę wojskowa) w prasie były i takie, które zostały skonfiskowane w ramach cenzury ${ }^{19}$. Tylko nieliczne ogłosił pod pseudonimem.

Niemniej Dembiński wzbudzał i wzbudza kontrowersje, o czym świadczą choćby tytuły poświęconych mu prac biograficznych, symptomatycznie oddających jego działalność: Tragiczne dzieje człowieka uczciwego ${ }^{20}$; Wspomnienia o Henryku D. człowieku dialogu $u^{21}$; Od kruchty do komuny: wileńskie manowce Henryka Dembinskiego ${ }^{22}$; Katolik, komunista, zdrajca?: Henryk Dembiński nadzieja wielu opcji politycznych $i$ jego droga do komunizmu $u^{23}$; Humanista przeciw defiladzie umartych bogów ${ }^{24}$; Henryk Dembiński-prekursor dialog $u^{25}$. Liczne publikacje biograficzne oddają jego drogę życiową i ewolucję poglądów społeczno-politycznych ${ }^{26}$, w tym monografia Leona Brodowskiego Henryk Dembinski. Człowiek dialogu ${ }^{27}$. Sa także dość bogate archiwalia ${ }^{28}$. Niemniej nie ma w literaturze konterfektu w kontekście jego związków z nauka prawa. Informacje o jego studiach prawniczych, działalności naukowo-dydaktycznej czy aktywności publikacyjnej w dziedzinie nauk prawnych maja zazwyczaj charakter szczątkowy i podawane sa niejako przy okazji poruszania innych zagadnień. A przecież jego sztandarowa praca nie zrodziła się w próżni. On sam był przedstawicielem wileńskiej szkoły prawa administracyjnego, kreowanej i moderowanej przez prof. Panejko. Jego wiedza wzrastała pod wpływem określonych prądów intelektualnych i koncepcji prawniczych, a zwłaszcza modnego wówczas kelsenizmu. Stąd też warto odnotować najważniejsze fakty z jego życia, z uwzględnieniem powyższych aspektów.

Henryk Dembiński studia na Wydziale Prawa i Nauk Społecznych Uniwersytetu Stefana Batorego w Wilnie rozpoczął w 1927 r. Po dwóch latach zaczął równolegle studiować filozofię. Był bardzo zaangażowanym żakiem. Mimo swojej szerokiej działalności społecznej, organizacyjnej i publicystycznej uchodził za wybitnego studenta prawa. Wystarczy wskazać, że tylko w roku

${ }_{19}$ Niepełny wykaz: Szulkin (1962): 293-304; niepełne uzupełnienie: Brodowski (1988): $46 \mathrm{n}$.

${ }^{20}$ Byrski (1971): 88-93.

${ }^{21}$ Szulkin (1973): 39-41.

${ }^{22}$ Korowajczyk (2002): 135-142.

${ }^{23}$ Chmielarz (2008): 110-118.

${ }^{24}$ Naszkowski (1971): 1 i 11.

${ }^{25}$ Brodowski (1965): 4.

${ }^{26}$ Oprócz wyżej przywołanych: Kornacki (1946): 21-49; Jędrychowska (1965), (1962): 5-42.

${ }^{27}$ Brodowski (1988).

${ }^{28}$ Archiwum Akt Nowych, Zespół: 2/1481/0 Akta Henryka Dembińskiego; Zespół: 2/2218/0 Archiwum Stanisława Stommy (a w tym: Z. Siemaszko, Henryk Dembiński. Dzieciństwo i wczesna młodość, ss. 10); Zespół: 2/1582/0 Zbiór akt osobowych działaczy ruchu robotniczego (przejęty z Centralnego Archiwum KC PZPR), Akta Henryka Dembińskiego, teczka os. nr 9027; Zespół: 2/1383/0 Urząd Wojewódzki Pomorski w Toruniu, Seria: 5.6 Starostwo Powiatowe w Świeciu, Jednostka: 273/VIII-7/8 Działalność komunistyczna oraz Seria: 1.1 Działalność komunistyczna, Jednostka: 273/I-6/11. 
akademickim 1929/30 za prace na ćwiczeniach z prawa karnego i opracowanie studium Prawo karne a moralność według Sołowiewa otrzymał pochwałę ${ }^{29}$.

W tym samym czasie publikuje swój pierwszy tekst stricte naukowy, a mianowicie recenzję pracy Stanisława Świaniewicza Psychiczne podłoże produkcji $w$ ujęciu Jerzego Sorela ${ }^{30}$. Niemniej odnajdywał się przede wszystkim w nauce administracji i prawa administracyjnego, co też niejednokrotnie znalazło wyraz w jego późniejszej publicystyce ${ }^{31}$, a przede wszystkim w nauce i w pracy własnej.

W roku akademickim 1929/30 Dembiński złożył jako jeden z dwóch studentów egzamin z oceną celującą u wymagającego prof. Panejko ${ }^{32}$. Na jego świadectwie udziału w niższym seminarium administracyjnym (które odbyło w pierwszym, drugim i trzecim trymestrze roku akademickiego 1929/1930) widnieje ocena celujacca, nadto prowadzacy prof. Panejko wystawił mu następująca opinię: „[...] przy omawianiu zagadnień administracyjnych wykazał znakomitą orientację i znajomość teorii prawa administracyjnego. Nadto wygłosił dwa referaty $\mathrm{z}$ dziedziny samorządu uniwersyteckiego [Istota samorzadu] i samorządu terytorialnego w Polsce [Idea przewodnia samorzadu terytorialnego $w$ Polsce], tudzież przedłożył pisemną pracę pt.: Reformatio in peius $w$ postepowaniu administracyjnym $w$ świetle teorii prawa administracyjnego" "33. Pewnym pokłosiem jednego z referatów była publikacja Zagadnienia ustroju instytucji samorzqdowych w lubelskim miesięczniku „Prąd”, poświęconym zagadnieniom religijnym, narodowym i społecznym ${ }^{34}$. Stąd też zapewne prowadzacy Seminarium Prawa Administracyjnego, a zarazem kierownik działającego przy Katedrze Nauki Administracji i Prawa Administracyjnego Zakładu Naukowego Administracji i Prawa Administracyjnego prof. Panejko pismem z 25 kwietnia 1930 r. wystapił z wnioskiem o mianowanie Dembińskiego (wtedy studenta III roku prawa) na stanowisko młodszego asystenta ${ }^{35}$.

Choć do asystentury ostatecznie nie doszło, to jednak nie zniechęciło to Dembińskiego do dalszego pogłębiania wiedzy z zakresu nauki administracji i prawa administracyjnego. W ramach wyższego seminarium administracyjnego w roku akademickim 1930/31 przedstawił bowiem następujące referaty: Zagadnienia karnoadministracyjne; Rozprawa w postepowaniu administracyj-

${ }^{29}$ Lietuvos centrinis valstybės archyvas, Zespół Uniwersytetu Stefana Batorego w Wilnie, sygn. 175. 2. VI B. 2b, Sprawozdanie z działalności Katedry Prawa i Procesu Karnego za rok akademicki 1929/1930. Rękopisy profesorów WPiNS USB, k. 32. Tarkowski (2009): 206.

${ }^{30}$ Dembiński (1929a): 191. (We wszystkich cytowanych tekstach przedwojennych zachowano pisownię oryginału).

31 Dembiński (1962).

32 Dąbrowski (2015): 319.

${ }^{33}$ Lietuvos centrinis valstybės archyvas, Zespół Uniwersytetu Stefana Batorego w Wilnie, sygn. 175. 2. VI B. 2b, Sprawozdanie seminarium administracyjnego za rok akademicki 1929/30 z nauki administracji i prawa administracyjnego. Rękopisy profesorów WPiNS, k. 41 i $41 \mathrm{v}$.

34 Dembiński (1929b): 180-188.

${ }^{35}$ Lietuvos centrinis valstybės archyvas, Zespół Uniwersytetu Stefana Batorego w Wilnie, mszp., sygn. 175. 2. VI B. 34i, Wniosek J. Panejko w sprawie zamianowania na stanowisko młodszego asystenta H. Dembińskiego. Pismo z 25 kwietnia 1930 roku, k. 8-8v. Szerzej: Tarkowski (2009): 214. 
nym; Charakter samorzqdu rzemieślniczego; Nabywanie obywatelstwa z traktatów międzynarodowych, które również zostały wysoko ocenione, a przede wszystkim napisał wyróżniona pracę $W$ poszukiwaniu form organizacyjnych przedsiębiorstw komunalnych ${ }^{36}$. Jak zostało wskazane na wstępie, ta ostatnia została opublikowana na łamach „Samorządu Terytorjalnego” i jej reprint ukazał się w $1990 \mathrm{r}$.

Jest to obszerny artykuł otwierający numer tego czasopisma, bazujacy na ustaleniach doktryny polskiej i piśmiennictwa kultury języka niemieckiego. Autor omawia w nim następujące kwestie: pojęcie zakładów i przedsiębiorstw komunalnych, charakter administracji twórczej i zwierzchniczej, przedsiębiorstwa czysto handlowo-przemysłowe, przedsiębiorstwa użyteczności publicznej, postulaty racjonalnej gospodarki przedsiębiorstw komunalnych, wadliwość administracji zwierzchniej, stosowanej przy przedsiębiorstwach komunalnych, postulaty prawno-organizacyjne, systemy niemieckie, system francuski. Na końcu formułuje oryginalne wnioski, w tym, że „[...] zasada polityki komunalnej ma być nie wycofywanie majątku gminnego z przedsiębiorstw użyteczności publicznej, lecz usprawnienie ich administracji” ${ }^{37}$. Praca była już przywoływana przed wojną i stanowiła ważny głos w dyskusji o pozycji prawnej przedsiębiorstw komunalnych. Niemniej w treści artykułu wiele uwagi autor poświęca sprawie osobowości prawnej i formułuje pogląd, zgodnie z którym: „[...] Zagadnienie usamodzielnienia przedsiębiorstw komunalnych tak, jak i zagadnienie rozbudowy samorządu - to tylko zagadnienie decentralizacji administracji. Osobowość prawna - to środek techniki prawnej. Pociaga ona za sobą jedynie skutki prawa prywatnego"38, choć uważa za słuszny postulat „nadania osobowości prawnej przedsiębiorstwom komunalnym”39. Już po tym opracowaniu widać krytyczne podejście Dembińskiego do problematyki osobowości publicznoprawnej.

Koresponduje z tym jego - stosunkowo ostra - recenzja podręcznika mgr. Witolda Reissa z Wilna Zarys prawa administracyjnego dla urzędników państwowych i samorzqdowych oraz słuchaczy szkót wyższych, która ukazała się w tym czasie na szpaltach „Ruchu Prawniczego, Ekonomicznego i Socjologicznego" ${ }^{40}$. Pikanterii sprawie dodaje fakt, że w recenzowanym podręczniku kwestie dotyczące związków publicznoprawnych zostały opracowane prawie wyłącznie na podstawie ustaleń Tadeusza Bigo.

Inna publikacją tego typu była przywołana na wstępie polemiczna recenzja pracy dr. Michała Króla Odpowiedzialność państw w prawie Narodów, w której Dembiński szeroko odwoływał do poglądów Hansa Kelsena. W pracy tej nie pojawia się - jak u prof. H. Dembińskiego - pojęcie osobowości publicz-

${ }^{36}$ Lietuvos centrinis valstybės archyvas, Zespół Uniwersytetu Stefana Batorego w Wilnie, sygn. 175.2. VI B, Sprawozdanie Seminarium Administracyjnego za rok 1930/31, dat., Wilno, 28 V 1931, mszp., k. 18, Świadectwo, sygn. 2VICa, apsk. 575, k. 19.

37 Dembiński (1930a): 492.

38 Dembiński (1930a): 484.

39 Dembiński (1930a): 489.

40 Dembiński (1931a): 25-29. 
noprawnej, ale rozróżnienie osobowości międzynarodowoprawnej oraz osobowości prawnopaństwowej.

Dembiński był zafascynowany nauką Kelsena. Nie tylko na potrzeby egzaminu z prawa administracyjnego opracował skrypt Teorje Duguit'a i Kelsena, wydany w 1931 r. na prawach rękopisu dla słuchaczy Uniwersytetu Stefana Batorego w Wilnie. Poglądy tytułowych twórców neopozytywizmu prawniczego były wtedy bardzo wpływowe w dziedzinie prawa publicznego. W skrypcie tym w sposób wyraźny odniósł się do zapatrywania Kelsena na pojęcie osobowości prawnej państwa. Pisał tam w sposób następujący: „[...] Jeżeli mówimy, że państwo jest osobą prawną nie znaczy to, ażebyśmy w tem pojęciu coś od prawa odrębnego lub coś przeciwstawiającego się prawu. Jeżeli się powie »osoba«, to socjolog, psycholog, przyrodnik będzie przez to rozumieć »człowiek«, natomiast prawnik widzi poza tym wyrazem kompleks norm zlanych w harmonijną jedność. Tak samo, jeżeli się powie "państwo", to socjolog, polityk, i t.p. widzi poza tym wyrazem związek ludzi, osobę nadnaturalna, organizm albo inny jakiś byt realny, natomiast prawnik widzi w pojęciu osobowości prawnej system pewnego kompleksu norm, jeżeli chodzi o państwo - widzi system całości norm. Tak więc pojęcie osoby jest jednoznaczne $\mathrm{z}$ pojęciem jedności systemu, tylko w tym sensie można mówić, że państwo jest osobą prawna" ${ }^{41}$.

Dembiński był pod silnym wpływem teorii Kelsena. Wpłynęło to na pomysł przygotowania większej pracy naukowej, którą napisał po ukończeniu służby wojskowej i która to praca stała się podstawą nadania mu w grudniu $1933 \mathrm{r}$. stopnia naukowego doktora, a potrzebne książki donosili mu koledzy ${ }^{42}$. Promocja doktorska odbyła się 19 stycznia 1934 r. w Auli Kolumnowej USB ${ }^{43}$. Już jako doktor wygłosił dla kolegów z Koła Studentów Prawników USB odczyt Forma prawna a jej ideologia ${ }^{44}$.

Stosownie do przepisów rozporządzenia Ministra Wyznań Religijnych i Oświecenia Publicznego z 11 listopada 1924 r. w sprawie uzyskania stopnia doktora na wszystkich wydziałach państwowych szkół akademickich ${ }^{45}$ praca ta ukazała się nakładem Księgarni Św. Wojciecha w Wilnie w 1934 r. Liczy 149 stron, co - na tle innych wcześniejszych prac tego typu powstałych pod kierunkiem prof. Panejko - pozwala ją uznać za obszerna ${ }^{46}$. Rozprawa ta pod względem konkluzji jest zasadniczo stosunkowo dobrze znana, ale należy wyraźnie podkreślić, że wpisuje się w kanon prac z zakresu państwowej teorii samorządu powstałych pod kierunkiem prof. Panejko, a więc w sensie dogmatycznoprawnym kwestionujących jako istotną cechę samorządu osobowość publicznoprawną. Na tle rozumienia wywodów autora dochodzi do wielu nieporozumień.

Rozprawa ta w aspekcie podziału treści jest logiczna i spójna. Składa się ze „Wstępu - Prowizorium pojęć” i trzynastu rozdziałów merytorycznych.

\footnotetext{
${ }^{41}$ Dembiński (1931b): 12.

42 Jędrychowska (1965): 102.

43 Słowo, 19 stycznia 1934: 3.

44 Kronika: Z Koła Prawników Stud. USB. (1934): 2.

45 Dz. Urz. MWRiOP 1924, nr 20, poz. 207.

46 Bar (1934) - ss. 63; Paczyński (1933) - ss. 87.
} 
Punktem wyjścia jest wyodrębnienie w perspektywie badawczej trzech pięter: 1), ,...] realny układ sił społecznych wyrażający się w zdecentralizowaniu maszynerii przymusu państwowego pomiędzy poszczególne grupy społeczne, istniejące wewnątrz obejmującej ją społeczności, jaką jest państwo”; 2) forma prawna tych realnych stosunków polityczno-społecznych („,całość stosunków prawnych pomiędzy grupa społeczną lub jednostka, posiadającą w swych rękach część przymusu państwowego, a grupa, zwierzchnio dysponująca całością maszynerji przymusu państwowego, oraz całokształt norm pozytywnie obowiąujących, a wyrażających te stosunki prawne, razem charakteryzuja konstrukcję prawną samorządu, albo też [...] jego formę prawną [...] stosunki polityczno-społeczne stają się podłożem, treścią formy prawnej i dlatego ta ostatnia jest dla nas drugiem piętrem"); 3) ideologia samorządu (,ideologją będzie taki system pojęć, powiązanych w sądy, który nie ogranicza się do wyjaśniania empirycznie danej rzeczywistości pojęciami ufundowanemi w tej rzeczywistości i dającemi się na podstawie elementów tej rzeczywistości sprawdzić odnośnie swej fałszywości lub prawdziwości. Ideologja jest to wykrzywione odźwierciadlenie rzeczywistości, a wykrzywiaja je te właśnie elementy pojęciowe, które, nie dając się sprawdzić empirycznie w badanej rzeczywistości, nie będąc w niej adekwatnie ufundowane, są fantasmagorją psychiki ludzkiej. Nauka stricto sensu będzie taki system pojęć, powiązanych w sądy, który wyjaśnia empirycznie daną rzeczywistość wyłącznie pojęciami, czerpiącemi swój sens i sprawdzalność z elementów tej rzeczywistości i będącemi jej adekwatnem odźwierciadleniem. Takie pojęcia ideologji i nauki są tylko idealnemi schematami logicznemi") ${ }^{47}$.

Wskazuje także, że „empirycznie badaną rzeczywistością dla dogmatyka jest pozytywnie obowiązujący porządek prawny. Forma prawna jest tu gotowym, w określonem miejscu i czasie zastygłym produktem socjalnym w postaci pozytywnie obowiązującego systemu norm i zadaniem dogmatyka jest, wyłącznie na podstawie elementów zawartych w tym empirycznie danym materiale, usystematyzować go w pewną logiczną jednośćc" „obok socjologicznej teorii formy prawnej może wreszcie istnieć socjologiczne badanie ideologji prawnej, polegające na wykrywaniu odpowiedników w rzeczywistości socjalnej, mistyfikujących się w konstrukcjach ideologicznych i wywołujących je" 49 .

Następnie uściśla: „Żywotność w danem miejscu i czasie danej ideologii samorządowej, lub danej formy prawnej samorządu stwarza nam presumpcję, że korzeniem ich żywotności jest pewien socjologiczny substrat w postaci właściwego im układu sił społecznych. Te zmiany w formie prawnej samorządu i jego ideologii, które warunkują się zmianami polityczno-społecznych stosunków samorządowych, nazwiemy strukturalnemi przemianami [...] Naukowe zrozumienie strukturalnych przemian formy prawnej samorządu i jego ideologii wymaga określonej metody badań. Trzeba ustalić, która z dwóch me-

\footnotetext{
47 Dembiński (1934): 3-5.

48 Dembiński (1934): 7-8.

49 Dembiński (1934): 10-11.
} 
tod: dogmatyczna czy socjologiczna jest tu właściwa. Dogmatyka bada formę prawna jako zastygły w miejscu i czasie kompleks empirycznie danego materiału prawnego, porządkuje w logiczną całość kompleks pozytywnie obowiązujaccych norm, wykluczając wszelkie elementy metaprawne, pozanormatywne. Porządkowanie to polega na tworzeniu pewnych uogólnień. Te uogólnienia, te abstrakcyjne pojęcia prawne dogmatyka, jak np. osoba prawna, organ i t. p., są wyłącznie rezultatem logicznego opracowania mnogości norm pozytywnego prawa. I tak pojęcie osoby prawnej jest dla dogmatyka niczem innem jak kompleksem poszczególnych aktów zachowania się jednostki lub grupy ludzkiej, dozwolonym lub nakazanym przez pozytywnie obowiązujący porządek prawny. Osoba prawna nie ma tu żadnego samoistnego bytu poza norma jest tylko, podyktowanym oszczędnością myślenia, skrótem myślowym kompleksu norm, regulujących zachowanie się danej jednostki lub grupy ludzkiej. Dogmatyka nie interesuje, dlaczego właśnie tym a nie innym jednostkom lub grupom przypisuja normy prawne takie a nie inne zachowanie się. Dogmatyk nie odpowie więc nam na pytanie, dlaczego istnieją takie a nie inne osoby, dlaczego maja takie a nie inne obowiązki i prawa. To już on ma z góry założone i gotowe w pozytywnie obowiązującym porządku prawnym. Dogmatyka zakłada więc statyczne istnienie gotowych norm. [...] Tam gdzie wchodzimy w akuszeryjne dziedziny stawania się norm prawnych, tam gdzie przystępujemy do badania strukturalnych przemian formy prawnej i jej ideologji - tam żegna nas dogmatyk, tam przychodzą do głosu realne stosunki społeczne i zaczyna się analiza socjologiczna" ${ }^{50}$.

$\mathrm{Na}$ tych podstawach stwierdza, że „[...] dla dogmatyka samorząd, jako konstrukcja prawna, będzie skrótem myślowym kompleksu norm, przekazujących zdecentralizowaną administrację państwową w ręce określonej grupy społecznej lub nawet jednostki, skrótem myślowym zachowania się tej grupy lub jednostki, nakazanego lub zezwolonego prawem, przyczem charakterystyczną i wyłącznie z norm wyczytaną cechą tego zachowania się jest samodzielność i niepodległość hierarchiczna wobec innych organów państwowych. Natomiast dlaczego danej grupie normy przypisują sprawowanie zdecentralizowanej administracji i dlaczego w takim a nie innym zakresie, oraz jakie przyczyny warunkują historyczną ewolucję tego zakresu, i dlaczego tym ewolucjom towarzyszy taka a nie inna ideologja samorządowa, - na to może odpowiedzieć tylko socjologiczna teorja formy prawnej samorządu"51.

W dalszej części, po charakterystyce sporu pomiędzy profesorami Panejko i Bigo, dla „[...] definitywnego zrozumienia różnicy pomiędzy pojęciami ściśle dogmatycznemi a ideologją dogmatyczna, która sens swój czerpie poza norma, zaciemniając nim czystość konstrukcyj dogmatycznych”, dokonuje kelsenowskiego zróżnicowania pomiędzy Rechtswesensbegriff i Rechtsinhaltsbegriff. Na tej podstawie uznaje, że „[...] istotę prawną danego pojęcia otrzymuje się

\footnotetext{
50 Dembiński (1934): 16-17.

51 Dembiński (1934): 18.
} 
w drodze naukowej analizy samej istoty prawa jako specyficznej formy i jego poszczególnych elementów”52. Powstanie wtedy naukowe, adekwatne pojęcie.

W konsekwencji rozróżnia dwa rodzaje pojęć techniczno-dogmatycznych. Jedne sa „,...] li tylko wytworzonymi w drodze logicznych uogólnień abstrakcjami, których używa nauka lub normodawca, ale które nie mają żadnego znaczenia normotwórczego [...] Drugi rodzaj pojęć techniczno-dogmatycznych jest również pewnem logicznem uogólnieniem zeskładu poszczególnych norm, różni się jednak od poprzedniego tem, że użycie tego uogólnienia przez normodawcę ma sens normotwórczy, gdyż stwarza pewne prawa i obowiązki, podporządkowuje pewnemu kompleksowi norm określone zachowanie się ludzkie, podciagnięte pod to uogólnienie"53.

Prowadzi to Dembińskiego do wstępnej konkluzji: „,[...] osobowość prywatno-prawna jest formą prawną samorządu, osobowość zaś publiczno-prawna w czystej dogmatyce prawa może być dowolnie stosowanem logicznem uogólnieniem, lecz w "grzesznej, po ziemi chodzącej« literaturze samorządowej jest czystą ideologją i niczem więcej" ${ }^{54}$.

Dalej, uznaje spór o osobowość publicznoprawną samorządu za dogmatycznie bezprzedmiotowy ${ }^{55}$, niemniej bada socjologiczne podłoże tej osobowości ${ }^{56}$. Konstatuje, że: „1) osobowość publiczno-prawna jest specyficzną ideologja, towarzyszącą takiej formacji społecznej, gdzie istnieje antagonizm wśród grup, sprawujących władztwo polityczne; 2) im większe jest zróżniczkowanie antagonistyczne grupy, dysponującej przymusem państwowym, tem intensywniej w ideologji prawnej rozmnażają się osoby publiczno-prawne; 3) w miarę stapiania się poszczególnych podgrup w jednolitą socjalnie grupę rządząca, w miarę monopolizacji przymusu państwowego $\mathrm{w}$ rękach jednolitej grupy zamieraja osoby publiczno-prawne, gdyż zanika walka polityczna wewnatrz aparatury władztwa politycznego, a tem samem gina psychiczne motory, pobudzające myśl ludzką do ideologicznego przetwarzania norm publiczno-prawnych we własne prawa podmiotowe; 4) decentralizacja jest tylko specyficzną formą rozwijania się porządku prawnego od norm ogólnych do zindywidualizowanych, przeto jest techniką organizacyjna, która może znaleźć swe zastosowanie w różnych układach sił społecznych; 5) przetwarzanie myślowe decentralizacji i organu zdecentralizowanego $\mathrm{w}$ prawo podmiotowe i osobę publiczna jest charakterystyczne dla takiego układu społecznego, gdzie grupa, sprawujaca zdecentralizowaną administrację lokalna, przeciwstawia się grupie, dzierżącej centrum władztwa politycznego, swemi w stosunku do tej centralnej grupy odrębnemi lub wręcz wrogiemi interesami" ${ }^{27}$.

Ówczesny magister, a powojenny profesor zwyczajny Jerzy Wiszniewski w swojej recenzji ogłoszonej w Dziale Samorządowym „Ruchu Prawniczego, Ekonomicznego i Socjologicznego” wskazuje, że „autor słusznie wykazuje błę-

\footnotetext{
52 Dembiński (1934): 30.

53 Dembiński (1934): 36.

${ }^{54}$ Dembiński (1934): 39.

55 Dembiński (1934): 41.

56 Dembiński (1934): 57.

${ }^{57}$ Dembiński (1934): 98-99.
} 
dy w rozumowaniu Bigi, który sugestjonując się tradycyjną teorją samorządu, upatruje jego istotę w osobowości publiczno-prawnej jego organów. Dembiński wykazuje, że posiadane przez samorząd publiczne prawa podmiotowe sprowadzają się w rzeczywistości do zera, że t. zw. "własne« prawa samorządu niczem się nie różnią co istoty od praw organów rządowych” ${ }^{58}$. Uważa też, że „praca Dembińskiego jest niezwykle ciekawa w swej II części socjologicznej. Teza o stopniowem zlewaniu się samorządu z administracją rządowa, jakkolwiek zupełnie udowodniona empirycznie, nie daje jednak naszem zdaniem podstawy do wysnucia może zbyt krańcowego twierdzenia autora o już dokonanem zlaniu się samorządu z administracją rządowa. Naszem zdaniem ten proces jest dopiero w toku i tylko może w ZSRR zlanie stało się rzeczą dokonana. W innych państwach ten proces może rozciagnąc się na długie lata i konstrukcja publicznych praw podmiotowych jeszcze na długo pozostanie w nauce, a także i w życiu praktycznem. Specjalna wartość pracy polega na jednoczesnem stosowaniu dwóch metod: dogmatycznej i socjologicznej w badaniu zjawisk prawnych, dzięki czemu praca autora wnosi dużo nowego materjału w aktualny dziśs spór pomiędzy szkoła czystej dogmatyki prawa Kelsena a przedstawicielami socjologicznego kierunku badania prawa. Autor uwzględnił w swej pracy nietylko literaturę samorządowa, ale także i współczesne zdobycze socjologji oraz ekonomji politycznej w zakresie analizowania prawa jako specyficznej formy stosunków społecznych"59.

Krytycznie ustosunkował się do rozprawy Dembińskiego Czesław Znamierowski, socjolog i prawnik, zdecydowany przeciwnik teorii Kelsena ${ }^{60}$, którego recenzja ukazała się w Dziale Prawniczym „Ruchu Prawniczego, Ekonomicznego i Socjologicznego" ${ }^{61}$. Na wstępie Znamierowski próbuje odgadnąć, czy recenzowana praca powstała „jako wytwór niezależnej refleksji bezinteresownej, czy też poza celem badawczym miała jakieś widoki utylitarne" ${ }^{2}$. W jego ocenie jest to praca napisana na stopień, co wywnioskowuje z tego, „w jaki sposób i w jakim stopniu wprowadzone zostały rzeczy nieistotne, dla »zaokraglenia kształtów“ pracy, która według mody panującej w ceremonjale promocyjnym musi mieć kształty pełne, jeśli nie myśli oryginalnej, to sieczki lub specjalnej waty, spreparowanej z poglądów dobranego odpowiednio lub nieodpowiednio autora, czy też z wielu autorów, wyselekcjonowanych w sposób podobny"63. Znamierowski ironizuje, że recenzowana praca odznacza się „balastem erudycyjnym” oraz „nieprzeciętnie szerokim horyzontem myśli, w normalnych bowiem pracach prawniczych w Polsce wystarcza posłuszny hołd dla Berlina i Wiednia" ${ }^{4}$.

\footnotetext{
58 Wiszniewski (1934): 684.

59 Wiszniewski (1934): 687.

60 Bosiacki (2014): 32 .

61 Znamierowski (1935a): 1-4.

62 Znamierowski (1935a): 1.

${ }^{63}$ Znamierowski (1935a): 1. W tym samym numerze zawarta jest też recenzja dzieła Kelsena, Czysta teoria prawa, w której Znamierowski (1935b) także krytycznie odnosi się do szkoły

${ }^{64}$ Znamierowski (1935a): 1
} wiedeńskiej. 
Dalej Znamierowski poddaje krytyce metodę Dembińskiego i zarzuca mu przeprowadzanie czytelnika przez „gasszcz zagadnień pozornych”65. W ocenie recenzenta: „Nasz autor nie jest zaprawiony do operowania nawet elementarnemi pojęciami logicznemi: o pojęciach np., które przed chwila analizował, powiada, że nie istnieja; to znów mówi, że nie wie, czy są prawdziwe, czy też fałszywe, co świadczy niezawodnie, że autor naprawdę nie wie, iż orzeczniki "prawdziwy" i »fałszywy" stosuja się tylko do zdań, nie stosują się natomiast do pojęć”66. Konkluzja recenzji również jest sarkastyczna: „Czy zastanowił się autor choć przez chwilę nad tem, jak można normę przekształcić na sytuację człowieka pośród innych ludzi, albo organ przerobić umysłowo na osobę? W jakiej uczelni można zdobyć tę moc niesamowitą? Fakt, że książki tego typu, co omawiana, mogą się ukazywać w druku, nasuwa refleksje bardzo poważne, smutne i gorzkie. Narzuca on konkluzje niemal drastyczne, co się tyczy konieczności gruntownego przekształcenia studjów prawniczych; podsuwa myśli diagnozę niemal oczywistą obecnego stanu tych studjów. Lecz próżna to rzecz rzucać $\mathrm{w}$ rosnący zmierzch bezimienne wezwania do nawrotu $\mathrm{z}$ tej drogi lekceważenia kultury. Któż zechce, nieprzymuszony, zastanawiać się dzisiaj nad obowiązkiem rzetelności intelektualnej? Myślę, że sam autor tej książki może zrozumieć szkodę, jaką ona i rzeczy jej podobne przynoszą wielkiej i doniosłej sprawie doskonalenia form życia społecznego. Autor przytacza w swej pracy pisarzy zza wschodniego kordonu. W tej dewocji jego dla poglądów, dyktowanych zgóry przez rację stanu najsmutniejszego na ziemi kraju, skłonny jestem widzieć nietylko admirację dla »realnej dialektyki« marksowskiej, lecz i wrażliwe czucie zła społecznego, które wymaga naprawy. Niechże tedy autor w ciszy swego pokoju, w samotności, która pozwala głośno odzywać się sumieniu, postawi sobie pytanie: czy jego książka istotnie ułatwia drogę do szczęśliwości społecznej?"67.

W recenzji rozprawy Dembińskiego zamieszczonej na łamach „Wileńskiego Przeglądu Prawniczego" jej autor (podpisany jedynie inicjałami) stwierdza: „Można w pewnych wypadkach nie zgadzać się z wywodami autora, w szczególności zaś można na przykład kwestjonować słuszność stanowiska autora, przyjmującego, iż w świetle dogmatycznym odnośnie osobowości publiczno-prawnej i prywatno-prawnej w samym materjale norm niema żadnych różnic, natomiast doszukującego się $\mathrm{w}$ tym względzie istotnych rozróżnień ze stanowiska socjologicznego. Podczas gdy osoby i prawo prywatne, w/g autora, sa formą prawną społecznej wymiany dóbr w ustroju towarowym, prawo i osoby publiczne mają być formą prawną władztwa politycznego oraz stosunków politycznych pomiędzy grupami. W istocie jednak w świetle socjologicznem prawo publiczne może być uważane również jako forma prawna społecznej wymiany dóbr i poprzez tę wymianę podziału dóbr. W tym przeto względzie raczej może bliższym jest prawdy powoływany przez autora uczony Paszukanis. Naogół jednak należy podkreślić, iż wywody autora jako też ustalone przez niego tezy

\footnotetext{
65 Znamierowski (1935a ): 2.

66 Znamierowski (1935a ): 3.

67 Znamierowski (1935a): 3-4.
} 
cechuje wielka ścisłość. Może li tylko pewne zastrzeżenie wzbudzać układ materjału i w związku z tem przejrzystość wykładu, co jednak nie podważa jego mocnej konstrukcji logicznej. Przede wszystkiem zaś należy z uznaniem stwierdzić, iż autor w swoich badaniach posługuje się, jak to dowodnie wykazała omawiana praca, metodą naukową właściwa" ${ }^{68}$.

Praca ta i jej autor zostali też ocenieni przy okazji omawiania innych problemów. Wacław Brzeziński uważa, że na tle sporu naukowego pomiędzy profesorem Panejko a profesorami Bigo i Wasiutyńskim „różnicę w przedstawieniu pojęcia samorządu przez obie strony możnaby ująć przy pomocy rozróżnienia, jakim posługuje się Dembiński (idący zresztą za rozróżnieniem kelsenowskim „Rechtswesensbegriff” i „Rechtsinhaltsbegriff”) w swojej cennej pracy metodologicznej na temat osobowości publiczno-prawnej samorzadu"69. Antoni Peretiatkowicz uznaje natomiast Dembińskiego za znawcę nauki Kelsena ${ }^{70}$. Praca Dembińskiego była także przywołana przez teoretyka prawa dr. Sawę Frydmana ${ }^{71}$.

Jego poglądami podpierał się także sam Panejko w drugim wydaniu swojej pracy Geneza $i$ podstawy samorzadu europejskiego ${ }^{72}$, a także w wydanej po wojnie w języku ukraińskim monografii z 1963 r. Теоретичні основи саловрядування (Teoretyczne podstawy samorzadu) ${ }^{73}$. Siła rzeczy do pracy Dembińskiego nawiązywali także powojenni uczniowie prof. Panejko, np. Roman Goliat, który uzyskał tytuł doktora prawa w 1949 r. na podstawie rozprawy pt. Ідеологічні переліни саловрядування (Zmiany ideologiczne samorzq$d u$ ) oraz Zenobiusz Sokoluk, który doktoryzował się w 1953 r. na podstawie dysertacji pt. Ідеологічні основи колунального саловрядування у Франиіі (Ideologiczne podstawy samorzadu komunalnego we Francji) ${ }^{74}$.

Inny charakter maja wypowiedzi Pawła Jasienicy oraz Stanisława Cata-Mackiewicza względem pracy Dembińskiego. Pierwszy z nich w swoim pamiętniku stwierdza, że jego znajomi prawnicy z kół liberalnych wyrażali się o niej bez entuzjazmu, a jeden z nich powiedział mu: „Ot, międlenie Marksa”75. Drugi też w swoich artykułach ogłoszonych w wileńskim „Słowie” powoływał się na analogiczne źródła inspiracji, ale kontynuował wcześniej wyrażone uprzedzenie (,Tatarzyn jest mi bliższy niż tego rodzaju komunista-katolik, jak p. Dembiński”) ${ }^{76}$. Dlatego też „Tytułem naukowym służy p. Dembińskiemu książka o samorządzie, w której zastosował on do samorządu tezy Lenina o państwie i rewolucji” ${ }^{77}$, albo „Dembiński napisał rozprawę doktorską o samorządzie. Jest taka broszura Lenina: Państwo a rewolucja. Dembiński przepi-

68 K.s. (1935): 21-23.

69 Brzeziński (1936): 61.

70 Peretiatkowicz (1937): 446.

71 Frydman (1936). Po II wojnie światowej zmienił personalia na Czesław Nowicki i był m.in. rektorem Szkoły Głównej Planowania i Statystyki w Warszawie (1949-1952).

72 Panejko (1934): 92, 111-112, 127, 131.

73 Panejko (1963): 89, 113, 127.

74 Dobkowski (2014): 59 n.

75 Jasienica (2007): 112.

76 Cat-Mackiewicz (1932): 1.

77 Cat-Mackiewicz (1935a): 3. 
sał jej tezy i zastosował do samorządu”78, tudzież „Na to, by profesorowi USB podsunać za pracę doktorska pospolita aplikację obcych wywodów, wyników obcej pracy myślowej, nie trzeba ani wiele talentu, ani nawet wiele sprytu"79.

Słowa te także były pośrednio kierowane do prof. Panejko, a asumptem do krytycznego nastawienia Cata-Mackiewicza był fakt, że profesor, wykładajacy w Szkole Nauk Politycznych przy Instytucie Naukowo-Badawczym Europy Wschodniej w Wilnie przedmioty: Zasady prawa administracyjnego oraz Struktura administracyjna ZSRR, w 1935 r., zrezygnował i na jego miejsce miał zostać zatrudniony właśnie dr Dembiński ${ }^{80}$, notabene dwukrotny stypendysta Funduszu Kultury Narodowej na wyjazdy naukowe do Wiednia i Rzymu. W Szkole Nauk Politycznych prowadził wykłady z zakresu prawa administracyjnego ${ }^{81}$. W tym okresie nie pisał prac naukowych ani popularnonaukowych, ale oddawał się on publicystyce, w której można odnaleźć argumentacje nawiąujace do prawa administracyjnego.

Podczas pobytu w areszcie dotyka go swoista infamia. Nie zarzuca jednak i tam pracy intelektualnej. Oddany swoim ideałom opracowuje projekt ustawy, który warto przytoczyć in extenso:

$\S 1$. Wszystkim, którzy chcą rządzić, nauczać i wychowywać, wszystkim, którzy występuja publicznie w imię dobra powszechnego i interesu publicznego, wszystkim, którzy sprawuja imperium publiczno-prawne we wszystkich instancjach aparatu państwowego, wszystkim posłom, senatorom, działaczom politycznym, mówcom przemawiającym na zgromadzeniach politycznym, wszystkim nauczycielom, profesorom uniwersytetu, redaktorom, dziennikarzom i publicystom, wszystkim działaczom publicznym i sługom społeczeństwa zakazuje się: a) posiadać i nabywać nieruchomości, pakiety akcji, działki budowlane itp.;

b) brać udział we władzach i organach administracyjnych prywatnych przedsiębiorstw i zakładów obliczonych na zysk;

c) ciagnąć w jakikolwiek sposób korzyści z majątków, posiadać i nabywać papiery wartościowe oraz ciagnąć korzyści z procentów od kapitału i dywidend, utajonych remunerariów, honorariów itp. (wyjątek: oszczędności na książeczce oszczędnościowej PKO).

$\S 2$. Jedynym źródłem dochodów dla wszystkich wyżej wymienionych działaczy publicznych jest ustawowo uregulowane uposażenie oraz ubezpieczenia społeczne i emerytalne.

Motywy ustawodawcze: sprawowanie władzy nad ludźmi, nauczanie, wychowanie, posłowanie, dziennikarstwo i publicystyka - wszystko to jest służba publiczną. Trzeba więc wybierać: albo służyć mamonie, albo społeczeństwu, albo używać rozkoszy, jakie daje posiadanie kapitału, kamienic, will, mająteczków, albo cieszyć się tym, co daje ambicja przewodzenia społeczeństwu, co daje rządzenie i tworzenie takiej czy innej kultury. Służba społeczeństwu, tak samo jak służba Bogu, jest zawodem, który wymaga specjalnych wyrzeczeń. Wymagając od działaczy publicznych celibatu w stosunku do kapitału i wstrzemięźliwego, dostatniego ubóstwa, umożliwia się tym ludziom poczucie czystości własnego sumienia i pewność, że kierują się w swej pracy wyłącznie interesem publicznym ${ }^{82}$.

Po zwolnieniu z aresztu śledczego za kaucja z powodu stanu zdrowia, w marcu 1938 r., Dembiński wyjeżdża do żony, która osiedliła się i pracowa-

\footnotetext{
78 Cat-Mackiewicz (1935c): 1.

79 Cat-Mackiewicz (1935b): 1.

80 Cat-Mackiewicz (1935a): 3.

${ }^{81}$ W roku akademickim 1936/37 r. wykłady te prowadził już prof. Wacław Komarnicki (zob. Prawo administracyjne. Skrypt według wykładów prof. W. Komarnickiego, Wilno 1937, ss. 192).

82 Jędrychowska (1962): $38 \mathrm{n}$.
} 
ła w Warszawie. Znajduje zatrudnienie w Państwowym Instytucie Kultury Wsi. Mieszkali w domu Warszawskiej Spółdzielni Mieszkaniowej i włączyli się w jej funkcjonowanie. Na jesieni 1938 r., w okresie kampanii wyborczej w wyborach samorządowych, Dembiński pod pseudonimem Henryk Kora publikuje cykl artykułów pod zbiorczym tytułem: Demokracja i samorzad. Niektóre z myśli tam zawartych warte sa odnotowania: „Samorząd terytorialny będzie jednocześnie przeplatać się i łacczyć z samorządem zawodowym, gospodarczym, ubezpieczeniowym i szkolnym. Demokracja w ramach poszczególnych jednostek terytorialnych będzie iść w parze z demokracją w ramach poszczególnych funkcyj życia zbiorowego. [...] Wszelka bowiem wspólnota zawodowa czy kulturalna nieoparta o więź sasiedzka, wynikającą ze wspólnego zamieszkiwania na zorganizowanej społecznie przestrzeni, jest wspólnotą niepełna, pokaleczona" "83. Warto także podkreślić, że Dembiński jako pierwszy zauważył konieczność odrębnego traktowania w ustroju samorządowym dużych osiedli mieszkaniowych, czy nawet organizacji administracji i planowania przestrzennego w wielkich aglomeracjach miejskich, jaką była niewątpliwie stolica ${ }^{84}$.

Szczególnie cenne jest jego własne określenie istoty samorządu: „Samorząd to nie pośredniczenie pomiędzy aparatem zawodowej biurokracji rządowej i obywatelem, to nie rada przyboczna władz administracji ogólnej, to w granicach zakreślonych prawem samodzielne i na własnych źródłach podatkowych oparte sprawowanie władzy publicznej przez wybranych przedstawicieli, będących w żywym i stałym kontakcie z ogółem obywateli, pod systematyczna kontrolą tego ogółu i przy jego masowej współpracy w lokalnych organach administracji samorządowej. Chcąc spełnić główne swe zadanie, czyli zbliżyć państwo do mas ludowych samorząd nie może być dodatkowym etapem na drodze od rządu do pojedynczego obywatela, nie może być megatonem władzy centralnej. Powinien być samodzielnym, wyposażonym w środki przymusu i niezbędny zakres swobodnego uznania, ośrodkiem dyspozycji politycznej, gospodarczej i kulturalnej na określonym wycinku terytorium" ${ }^{85}$.

W pozytywnoprawnym postrzeganiu samorządu bez cechy osobowości publicznoprawnej i pojęć towarzyszących, jak prawo do samorządu czy własny zakres działania, był konsekwentny do końca, choć już wtedy Konstytucja kwietniowa w odniesieniu do jednostek samorządowych i ich związ-

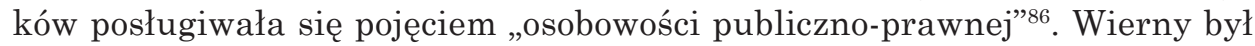
zatem swojemu mistrzowi naukowemu - prof. Panejko. Myślę, że łączyło ich coś więcej niż relacje naukowe, a także swoista przyjaźń. Obydwaj byli wrażliwi na piękno i sztukę. Obydwaj byli równie interesującymi co kontrowersyjnymi i tragicznymi postaciami. Fatalizm ich losów pogłębia fakt, że obydwaj zostali skazani przed podziemny polski wymiar sprawiedliwości i razem figuruja w komunikacie opublikowanym w konspiracyjnym Organie

\footnotetext{
${ }^{83}$ Kora (1938b): 3.

${ }^{84}$ Por. Zawadzki (1967a): 29-33; (1967b): 12-13.

85 Kora (1938): 216.

86 Zob. art. 75 Ustawy konstytucyjnej z 23 kwietnia 1935 r., Dz. U. Nr 30, poz. 227.
} 
Biura Informacji i Propagandy wileńskiej Armii Krajowej „Niepodległość” nr 10 z data $1-15$ grudnia 1942 r. $^{87}$

Dembiński może nie był najwybitniejszym administratywistą II Rzeczypospolitej, ale z pewnościa jego poglądy na samorząd są warte uwagi i refleksji, zarówno dla prawnika, jak i może bardziej dla socjologa prawa. Interpretował koncepcje osobowości publicznoprawnej samorządu jako prawnik dogmatyk, ale także poddawał ją analizie w kategoriach ideologiczno-socjologicznych. Jego publicystyka dostarcza także argumentów co do wyrobienia socjologicznego. Pod koniec życia intelektualnie blisko mu było do środowiska socjologów polskich. Będąc w już w Warszawie, nawiązał współpracę ze Stanisławem Ossowskim i Józefem Chałasińskim. Był redaktorem pośmiertnego tomu pism wybranych znanego polskiego socjologa kultury Stefana Czarnowskiego, wydanego przez Polski Instytut Socjologiczny ${ }^{88}$.

W „Przeglądzie Socjologicznym” z 1939 r. publikuje recenzję książki Antoniego Peretiatkowicza ${ }^{89} \mathrm{z}$ ciekawym stwierdzeniem w obronie kelsenizmu, że „Teorię Kelsena zwyciężyły nie argumenty uczonych, lecz Mussolini i Hitler”, oraz rozbudowana recenzję opracowania zbiorowego Ogólna nauka o prawie. Studia pod redakcją Bronisława Wróblewskiego ${ }^{90}$, w której znajduje się następujący passus: „Większość wymienionych prac może zainteresować socjologa chyba tylko jako materiał doświadczalny dla badań nad ideologia prawna i dogmatyką prawa”. Trzyma się zatem pierwotnego rozróżnienia, które przyjął w rozprawie doktorskiej. Można je określić współcześnie przez przymiotniki „prawne” i ,prawnicze”.

W zakresie socjologii przygotował jeszcze przed wojną maszynopis dużej pracy naukowej poświęconej problematyce chłopskich ruchów społecznych w XIX w. ${ }^{91}$ Dlatego zapewne jego dane osobowe figurują w Stowniku biograficznym socjologii polskiej ${ }^{92}$. W polskim piśmiennictwie prawnoadministracyjnym będzie jednak zawsze kojarzony jako autor rozprawy Osobowość publiczno-prawna samorzqdu w świetle metody dogmatycznej $i$ socjologicznej, której kluczowe ustalenie to to, że kontekst ideologiczno-socjologiczny jest ważny, ale nie rozstrzygajacy w kwestii istoty prawnej samorząu terytorialnego. Pod tym względem można się nie zgadzać co do umniejszania znaczenia, a nawet negowania osobowości publicznoprawnej samorządu, lecz książka ta jest określonym punktem widzenia, który należy ciagle brać pod uwagę.

Jarostaw Dobkowski

Uniwersytet Warmińsko-Mazurski w Olsztynie

j.dobkowski@uwm.edu.pl

https://orcid.org/0000-0002-2010-4152

${ }^{87}$ Por. Kania (2010): 60, gdzie błędna informacja o zamordowaniu Dembińskiego w Ponarach.

88 Czarnowski (1939).

89 Dembiński (1939a): 388-390.

90 Dembiński (1939b): 390-396.

91 Brodowski (1988): $46 \mathrm{n}$.

92 Wincławski (2001): 133-134. 
Bar, L. (1934). Czynniki kontroli w samorządzie terytorialnym. Poznań-Warszawa-Wilno-Lwów. Bosiacki, A. (2014). Wstęp, [w:] H. Kelsen, Czysta teoria prawa. Tłum. R. Szubert, red. A. Bosiacki. Warszawa.

Bosiacki, A. (2018). Doktryny samorządu terytorialnego II Rzeczypospolitej i ich znaczenie we współczesnej Polsce, [w:] E. Mreńca, P.B. Zientarski, B. Czwojdrak (red.), Administracja państwowa i samorząd w Polsce w ujęciu historyczno-prawnym Wybrane zagadnienia. Warszawa: 81-112.

Brodowski, L. (1965). Henryk Dembiński - prekursor dialogu. Słowo Powszechne 71: 3.

Brodowski, L. (1988). Henryk Dembiński. Człowiek dialogu. Warszawa-Kraków.

Brzeziński, W. (1936). Pojęcie prawne samorządu terytorialnego według ustawodawstwa obowiązującego w b. Dzielnicy pruskiej. Samorząd Terytorialny 8(1/2): 26-64.

Bujnowski, J. (1981). Obraz międzywojennej literatury wileńskiej (skrót większej całości). Poezja 5/6(186/187): 3-18.

Byrski, T. (1971). Tragiczne dzieje człowieka uczciwego (W 30 rocznicę śmierci Henryka Dembińskiego). Więź 9: 88-93.

Cat-Mackiewicz, S. (1932). Pojęcia pomieszane i niepomieszane. Słowo, 5 marca 1932: 1.

Cat-Mackiewicz, S. (1935a). Filo i Anty. Bolszewicka agitacja w Polsce. Słowo, 25 stycznia 1935: 3.

Cat-Mackiewicz, S. (1935b). Generalne premiowanie kombinatorstwa. Słowo, 11 marca 1935: 1.

Cat-Mackiewicz, S. (1935c). Kształcenie agitatorów komunistycznych w hierarchii wydatków państwa. Słowo, 3 marca 1935: 1.

Chmielarz, W. (2008). Katolik, komunista, zdrajca?: Henryk Dembiński - nadzieja wielu opcji politycznych i jego droga do komunizmu. Przegląd Powszechny 4: 110-118.

Czarnowski, S. (1039). Społeczeństwo - kultura: prace z socjologii i historii kultury. Warszawa.

Dąbrowski, P. (2015). Nauczanie nauki administracji i prawa administracyjnego na Wydziale Prawa i Nauk Społecznych Uniwersytetu Stefana Batorego w Wilnie w okresie dwudziestolecia międzywojennego. Czasopismo Prawno-Historyczne 67(1): 299-322.

Dembiński, H. (1929a). Recenzja: Stanisław Świaniewicz, Psychiczne podłoże produkcji w ujęciu Jerzego Sorela, Wilno 1929. Alma Mater Vilnensis 8: 161-162.

Dembiński, H. (1929b). Zagadnienia ustroju instytucji samorządowych. Prąd 3: 180-188.

Dembiński, H. (1930a). Poszukiwanie form organizacyjnych przedsiębiorstw komunalnych. Samorząd Terytorjalny 2(3/4): 1-28.

Dembiński, H. (1930b). Recenzja: Król M. Dr.: Odpowiedzialność państw w prawie Narodów. Wilno, 1929. Ruch Prawniczy, Ekonomiczny i Socjologiczny 10(3): 497-503.

Dembiński, H. (1931a). Recenzja: Reiss Witold Mgr.: Zarys prawa administracyjnego dla urzędników państwowych i samorządowych, oraz słuchaczy szkół wyższych, Tom I., Wilno, Zawadzki, 1930. Ruch Prawniczy, Ekonomiczny i Socjologiczny 11(1): 25-29.

Dembiński, H. (1931b). Teorje Duguit’a i Kelsena. Wilno.

Dembiński, H. (1934). Osobowość publiczno-prawna samorządu w świetle metody dogmatycznej i socjologicznej. Wilno.

Dembiński, H. (1939a). Recenzja: Antoni Peretiatkowicz: Studia Prawnicze. Poznań 1938. Str. 211. Przegląd Socjologiczny 7(1/2): 388-390.

Dembiński, H. (1939b). Recenzja: Ogólna nauka o prawie. Studia pod redakcja prof. Bronisława Wróblewskiego. Tom I, str. 405. Wilno 1936. Tom II, str. 300. Wilno 1938. Przegląd Socjologiczny 7(1/2): 390-396.

Dembiński, H. (1962). Wybór pism. Oprac. M. Szulkin. Warszawa.

Dembiński, H.M. (1934). Prawa zasadnicze państw w teorji prawa narodów. Przegląd Prawa i Administracji imienia Ernesta Tilla: rozprawy i zapiski literackie 59: 109-120.

Dobkowski, J. (2014). Jerzy Karol Panejko - zarys biografii. Studia Prawnoustrojowe 26: 47-62.

Frydman, S. (1936). Dogmatyka prawa w świetle socjologii [studium I: o wykładni ustaw], [w:] B. Wróblewski (red.), Ogólna nauka o prawie. Tom 1. Wilno: 141-316.

Herling-Grudziński, G. (1998). Wyjścia z milczenia: szkice. Warszawa.

Jasienica, P. (2017). Pamiętnik. Warszawa.

Jegelevlčius S. (1977). Rok 1939 - rabunek archiwów wileńskich. Przegląd Wschodni 4: 381-394.

Jędrychowska, A. (1962). Wspomnienie o Henryku Dembińskim, [w:] H. Dembiński, Wybór pism, Oprac. M. Szulkin. Warszawa: 5-42.

Jędrychowska, A. (1965). Zygzakiem i po prostu. Warszawa. 
Jędrychowski, S. (1967). Wspomnienia. Życie Osiedli Warszawskiej Spółdzielni Mieszkaniowej 2: $2-3$.

Kania, L. (2010). Organizacja i funkcjonowanie podziemnego wymiaru sprawiedliwości na Wileńszczyźnie w latach II wojny światowej (1940-1945). Studia Lubuskie 6: 49-85.

Kora [właśc. Dembiński] H. (1938a). Demokracja i samorząd. Życie Warszawskiej Spółdzielni Mieszkaniowej, Stowarzyszenia »Szklane Domy« Oddziału Robotniczego Towarzystwa Przyjaciół Dzieci na Żoliborzu i Gospody Spółdzielczej 11: 216-222.

Kora [właśc. Dembiński] H. (1938b). Perspektywy demokracji dzielnicowej w stolicy. Gazeta Robotnicza, 15 grudnia 1938: 3.

Kornacki, J. (1946). Słowo o D., [w:] H. Boguszewska, Ludzie wśród ludzi. Warszawa: 21-49.

Korowajczyk, W. (2002). Od kruchty do komuny: wileńskie manowce Henryka Dembińskiego. Arcana: Kultura, Historia, Polityka 45: 135-142.

Kronika: Z Koła Prawników Stud. USB. (1934). Słowo, 22 stycznia 1934: 2.

K.s. (1935). Recenzja: Henryk Dembiński. Osobowość publiczno-prawna samorządu w świetle metody dogmatycznej i socjologicznej. Wilno 1934, str. 149. Wileński Przegląd Prawniczy 1: $21-23$.

Maciejewski, T. (2012). Wybitni administratywiści w II Rzeczypospolitej. Gdańskie Studia Prawnicze 28: 201-215.

Mackiewicz, J. (1967). Legendy i rzeczywistości. Wiadomości 49(1131), 3 grudnia 1967: 1-2.

Miłosz, C. (1997). Abecadło Miłosza. Kraków.

Naszkowski, M. (1971). Humanista przeciw defiladzie umarłych bogów. Polityka 32: 1 i 11.

Paczyński, S. (1933). Czynniki techniczno-prawne w organizacji związków komunalnych. Wilno.

Panejko, J. (1934). Geneza i podstawy samorządu europejskiego. Wilno.

Panejko, Ju. (1963). Teoretyczni osnowy samowriaduwannia. Monachium 1963.

Peretiatkowicz, A. (1937). Teoria prawa i państwa H. Kelsena. Ruch Prawniczy, Ekonomiczny i Socjologiczny 17(4): $445^{*}-508^{*}$.

Putrament, J. (1962). Pół wieku. Tom 1: Młodość. Warszawa.

Strzeszewski, C. (1958). Ś. p. Henryk Dembiński. Roczniki Nauk Społecznych 2: 5-9.

Sukiennicki, W. (1967). Legenda i rzeczywistość. Wspomnienia i uwagi o dwudziestu latach Uniwersytetu Stefana Batorego w Wilnie. Paryż.

Swięcicki, B.W. (1971). Henryk Dembiński a wileński Kurier Powszechny. Pamiętnikarstwo Polskie 2: 107-112.

Szulkin, H. (1973). Wspomnienia o Henryku D. człowieku dialogu. Biuletyn Towarzystwa Kultury Moralnej 2: 39-41.

Szulkin, M. (1962). Bibliografia prac Henryka Dembińskiego, [w:] H. Dembiński, Wybór pism. Oprac. M. Szulkin. Warszawa: 293-304.

Tarkowski, M. (2009). Prawo publiczne na Uniwersytecie Stefana Batorego w Wilnie. Zeszyty Prawnicze UKSW 9(1): 191-217.

Uszyńska, R. (1985). Dembiński Henryk (1908-1941), [w:] Słownik biograficzny działaczy polskiego ruchu robotniczego, red. F. Tych. Tom 1: A-D. Warszawa 1985: 563-564.

Wincławski, W. (2001). Dembiński Henryk (1908-1941), [w:] Słownik biograficzny socjologii polskiej. Tom 1: A-H. Warszawa: 133-134.

Wiszniewski, J. (1934). Recenzja: Dembiński Henryk: Osobowość publiczno-prawna samorządu w świetle metody dogmatycznej i socjologicznej. Wilno, Księgarnia Św. Wojciecha, 1934, str. 149. Ruch Prawniczy, Ekonomiczny i Socjologiczny 14(3): 684-687.

Zagórski, W. (1977). Wolność w niewoli. Londyn 1971.

Zawadzki, S. (1967a). Henryk Dembiński o samorządzie Warszawy. W 25 rocznicę śmierci. Samorząd Robotniczy 1: 29-33.

Zawadzki, S. (1967b). Z problematyki samorządu lokalnego (wspomnienia o Henryku Dembińskim). Gospodarka i Administracja Terenowa 5: 12-13.

Znamierowski, C. (1935a). Recenzja: Dembiński Henryk: Osobowość Publiczno-Prawna Samorzadu w świetle metody dogmatycznej i socjologicznej. Wilno 1935. str. 149. Ruch Prawniczy, Ekonomiczny i Socjologiczny 15(1): 1-4.

Znamierowski, C. (1935b). Kelsen Hans: Czysta teorja prawa. Warszawa, Przedruk z Gazety Administracji i Policji Państwowej, 1935, str. 67. Ruch Prawniczy, Ekonomiczny i Socjologiczny 15(1): 4-7. 
Żukowski, P.M. (2014). Dembiński Henryk Marian Józef Leon Ignacy, herbu Nieczuja, [w:] D. Malec (red.), Profesorowie Wydziału Prawa Uniwersytetu Jagiellońskiego. Tom 2: 1780-2012. Kraków: 78-80.

\section{HENRYK DEMBIŃSKI (1908-1941) AND HIS VIEWS ON THE ESSENCE OF LOCAL SELF-GOVERNMENT}

\section{Sum mary}

The article presents Henryk Dembiński's views on the essence of local self-government through the prism of the notion of public-law personality. His key finding is that the ideological and sociological context is important, but not conclusive as to the legal essence of local government. In this respect, one can disagree with Henryk Dembiński's downgrading or even denying the public-law personality of local self-government. However, while his views represent a particular perspective, they must always be taken into account when considering this issue.

Keywords: local self-government; public-law personality; Henryk Dembiński 